\title{
Seasonal and spatial variations of snow chemistry on Mount Logan, Yukon, Canada
}

\author{
Kumiko GOTO-AZUMA, ${ }^{1}$ Roy M. KOERNER, ${ }^{2}$ Michael N. DEMUTH, ${ }^{2}$ \\ Okitsugu WATANABE ${ }^{1}$ \\ ${ }^{1}$ National Institute of Polar Research, Kaga 1-9-10, Itabashi-ku, Tokyo 173-8515, Japan \\ E-mail: kumiko@pmg.nipr.ac.jp \\ ${ }^{2}$ Geological Survey of Canada, 601 Booth Street, Ottawa, Ontario K1A OE8, Canada
}

\begin{abstract}
Three ice cores were recovered on or near Mount Logan, Yukon, Canada, at 3017, 4135 and $5340 \mathrm{~m}$ a.s.l. in 2002. Prior to ice-core drilling, we collected snow-pit and shallow core samples from Mount Logan in 2001 to study seasonal and spatial variations of snow chemistry. We dug snow pits at six sites between 2420 and $5340 \mathrm{~m}$ a.s.l. before the beginning of the melt season, with the exception of a pit at $3180 \mathrm{~m}$ a.s.l., where the melt season had just started but had affected only the near-surface stratigraphy. Three of the pits were extended deeper with a shallow core. The snow-pit and core samples were analyzed for ion chemistry and $\delta^{18} \mathrm{O}$. A series of depth profiles of ions and $\delta^{18} \mathrm{O}$ shows spatial variations, though characteristic peaks can usually be traced across all the profiles. Concentrations and deposition fluxes of $\mathrm{Na}^{+}$and $\mathrm{Cl}^{-}$, which are mainly of sea-salt origin, decrease with altitude. On the other hand, deposition fluxes of $\mathrm{NO}_{3}{ }^{-}, \mathrm{SO}_{4}{ }^{2-}, \mathrm{Ca}^{2+}$ and $\mathrm{NH}_{4}{ }^{+}$show a weak positive relationship with elevation below the summit plateau. Stable isotopes $\left(\delta^{18} \mathrm{O}\right)$ decrease with altitude, with a distinctive jump between 3200 and $4500 \mathrm{~m}$ a.s.l., as was reported previously. Stable isotopes $\left(\delta^{18} \mathrm{O}\right), \mathrm{Cl}^{-}, \mathrm{CH}_{3} \mathrm{SO}_{3}{ }^{-}(\mathrm{MSA}), \mathrm{Na}^{+}$and $\mathrm{Ca}^{2+}$ show clear seasonal variations, which would enable us to date the cores by annual-layer counting.
\end{abstract}

\section{INTRODUCTION}

During the last few decades, studies on polar ice cores have extensively widened our knowledge of the past climate and environment (e.g. Legrand and Mayewski, 1997). In the Arctic, most of the previous ice-core sites have been in the North Atlantic sector. The North Pacific sector, where climate variability is characterized by climate regimes (e.g. Trenberth, 1990; Trenberth and Hurrell, 1994; Mantua and others, 1997) and has tropical connections (Moore and others, 2001), also plays a key role in the global climate system. Ice cores from the North Pacific sector, although few in number, have demonstrated that they can provide us with a range of valuable information about past climate and environmental variability, such as atmospheric circulation (Moore and others, 2002; Wake and others, 2002), biomass burning (Holdsworth and others, 1996), volcanic activity (Holdsworth and Peake, 1985; Yalcin and others, 2003), forest fire activity (Yalcin and others, 2006a) and anthropogenic atmospheric changes (Yalcin and Wake, 2001). Previous studies on these ice cores have also suggested that cores from different altitudes record different environmental signatures (Holdsworth and Peake, 1985; Yalcin and Wake, 2001; Yalcin and others, 2003). It has been recognized that more ice-core records are needed in this region to extend the temporal, spatial and altitudinal coverage. To understand the temporal, spatial and altitudinal variability of the past climate and environment in the North Pacific sector of the Arctic, three ice cores were recovered on or near Mount Logan, Yukon, Canada (Goto-Azuma and others, 2003; Shiraiwa and others, 2003; Fisher and others, 2004; Yalcin and others, 2006a, b). The cores were drilled at 3017, 4135 and $5340 \mathrm{ma}$ a.s.l. in 2002 by the University of New Hampshire/University of Maine, USA, the National Institute of Polar Research, Japan, and the Geological Survey of Canada, respectively. Along with ice-core drilling, snow-pit studies were carried out in 2000, 2001 and 2002.
A distinctive altitudinal variation in stable isotopes of snow on Mount Logan has been reported in previous papers (Holdsworth and others, 1991; Holdsworth, 2001; Holdsworth and Krouse, 2002). These studies indicate that the moisture source for higher sites is different from that for the lower sites. This finding would provide important insight into the interpretation of stable-isotope data from the three ice cores. Detailed studies on snow chemistry at different altitudes together with stable isotopes are needed to translate the ice-core chemistry data into information about the past climate, environment and atmospheric chemistry. However, until recently such studies have been few in this region. While Holdsworth and others (1988) have reported the concentration of $\mathrm{Cl}^{-}, \mathrm{NO}_{3}{ }^{-}$and $\mathrm{SO}_{4}{ }^{2-}$ in snow pits at different altitudes in Yukon, they have not analyzed any cations. Furthermore, though they found no simple relationship between $\mathrm{NO}_{3}{ }^{-}$concentrations and altitude, their analysis was limited to $\mathrm{NO}_{3}{ }^{-}$. It should also be noted that not all the data used in their analysis are averaged over the same time-span. Therefore, more systematic and extensive studies have been needed to access seasonal and altitudinal variations of snow chemistry. Using results obtained from the snow-pit and shallow core samples collected on Mount Logan in 2001, when the most intensive pit studies were conducted, we investigate primarily the seasonal and altitudinal variations in concentrations and deposition fluxes of chemical constituents in snow, which provide valuable information about sources, transport and deposition of the chemical constituents.

\section{FIELDWORK AND LABORATORY ANALYSIS}

In May and June 2001, pit-wall samples were collected at six sites on Mount Logan. Locations of the pits and the dates of sampling are depicted in Figure 1 and Table 1. Sampling sites QSD and QS are located on Quintino Sella Glacier; 


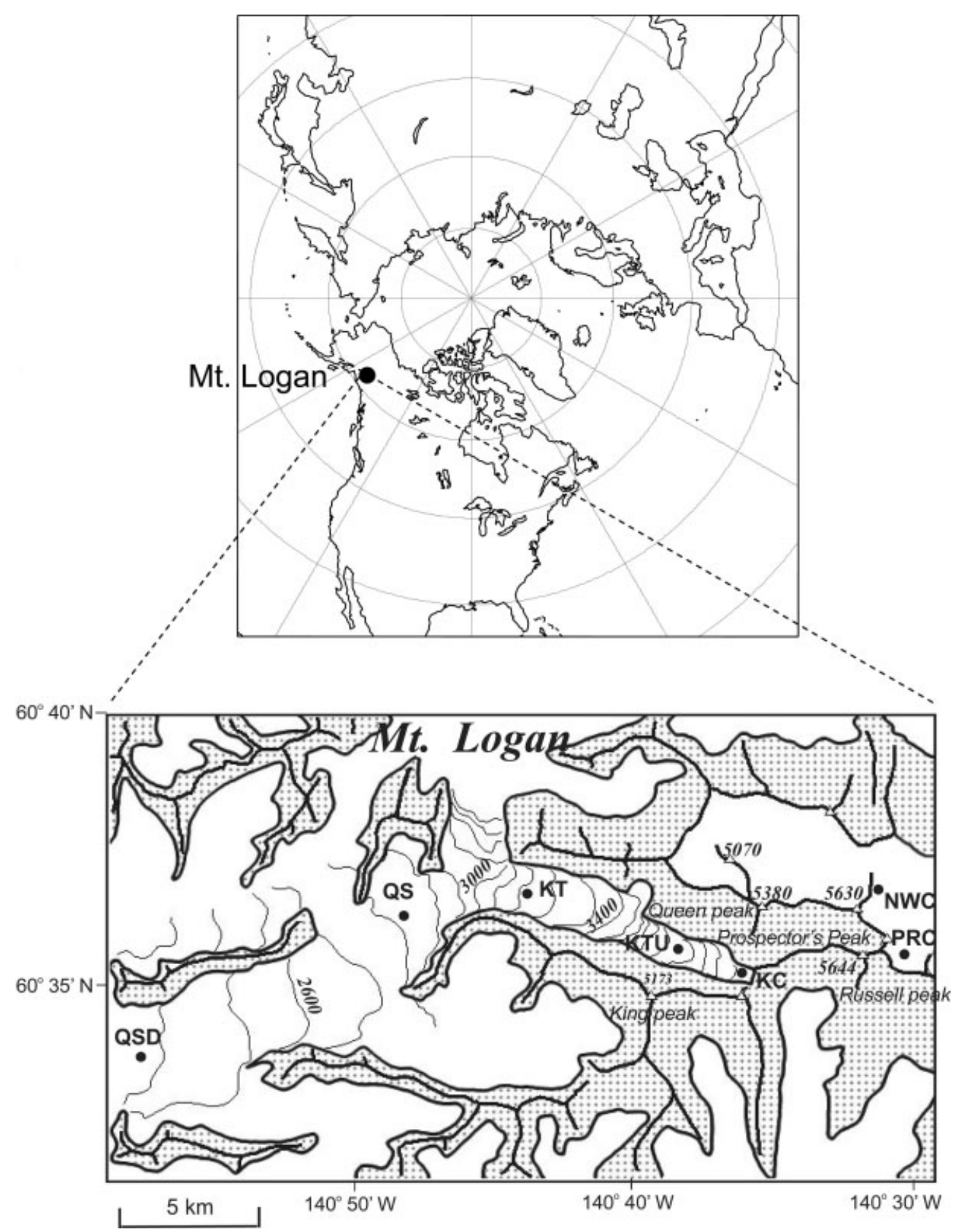

Fig. 1. Map of the sampling sites on Mount Logan in 2001.

sites KT and KTU in the King Trench; site KC at King Col; and site PRC at Prospector-Russell Col on the high plateau. Altitudes of the sampling sites range between 2420 and $5340 \mathrm{~m}$ a.s.I. Sampling at each site was carried out before the beginning of the melt season, with the exception of KT, where the melt season had just started but had affected only the near-surface stratigraphy.

After observation of the stratigraphy in each pit, samples were collected from a pre-cleaned wall using a stainlesssteel knife, previously cleaned by rinsing with ultrapure water. Pit-wall samples were taken vertically, and continuously, from the snow surface to depths of $1-4.3 \mathrm{~m}$, with the exception of PRC, where $0.03 \mathrm{~m}$ long samples were taken at a $0.05 \mathrm{~m}$ interval. Vertical sample lengths were approximately $0.03-0.1 \mathrm{~m}$. All the samples were collected into Whirlpak bags (Nasco) and melted in a tent in the field by personnel wearing disposable plastic gloves. In addition to the pit-wall samples, a shallow core was drilled at KT,
KTU and KC from the bottom of the pit with a hand auger. Depths of the cores are shown in Table 1. The cores were cut into approximately $0.1-0.15 \mathrm{~m}$ segments with a hand saw. The surface of each core segment from KTU and KC was scraped off with a previously cleaned stainless-steel knife for decontamination by personnel wearing disposable plastic gloves. The core samples from KT, however, were simply cut with the hand saw and put in Whirlpak bags, with no decontamination procedure. The core samples from all the sites were melted in Whirlpak bags, and the pit and core samples were then decanted into pre-cleaned plastic bottles in the tent and refrozen for transport to Japan. During the sampling and melting of the pit and core samples, special care was taken to avoid sample contamination. The bottled samples were kept frozen during transport and until just prior to laboratory analysis.

All the bottled samples were melted in a class 10000 clean room at the National Institute of Polar Research, Japan, 


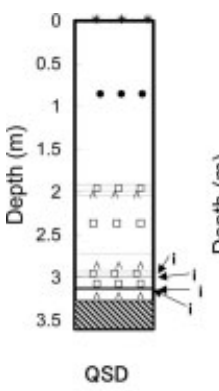

SD

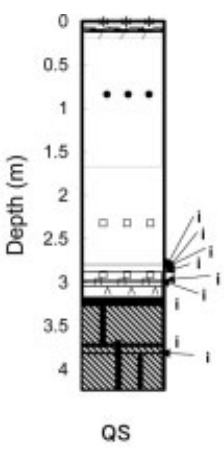

QS

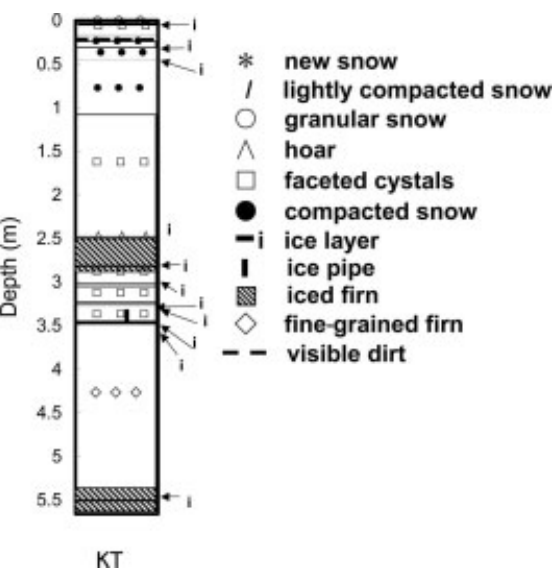

Fig. 2. Visible stratigraphy at QSD, QS and KT.

and analyzed for ions and $\delta^{18} \mathrm{O}$, except for those of the KT core, which were only analyzed for $\delta^{18} \mathrm{O}$. Soluble ions including $\mathrm{Cl}^{-}, \mathrm{NO}_{3}{ }^{-}, \mathrm{SO}_{4}{ }^{2-}, \mathrm{CH}_{3} \mathrm{SO}_{3}{ }^{-}(\mathrm{MSA}), \mathrm{Na}^{+}, \mathrm{K}^{+}$, $\mathrm{NH}_{4}{ }^{+}, \mathrm{Ca}^{2+}$ and $\mathrm{Mg}^{2+}$ were analyzed with an ion chromatograph (Dionex Dx-500) in the clean room. Stable isotopes $\left(\delta^{18} \mathrm{O}\right)$ were analyzed with a mass spectrometer (Mat DeltaPlus) in the laboratory next to the clean room.

\section{RESULTS AND DISCUSSION}

\section{Visible stratigraphy}

At sites QSD, QS and KT, where summer melting regularly takes place and forms distinctive melt layers, visible stratigraphy of the pits and the shallow core allowed easy identification of the end of the previous summer (summer 2000) melt season. Hereafter, we use the term 'summer surface' for the end of the summer melt season. Visible stratigraphy at QSD, QS and KT is presented in Figure 2.

At QSD, the following sequence was observed: (1) compacted snow, with $10 \mathrm{~mm}$ thick new snow on top (0$1.91 \mathrm{~m})$; (2) a mixture of loose hoar layers and facetedcrystal layers containing thin $(1 \mathrm{~mm})$ ice layers $(1.91-$ $3.27 \mathrm{~m}$ ); and (3) thick iced firn down to the bottom of the pit (3.27-3.60 m). Layers (1), (2) and (3) correspond to winter/spring 2000/01, late summer/fall 2000 and midsummer 2001, respectively. Similarly, visible stratigraphy at QS exhibited the following sequence: (1) winter/spring layers, consisting of new snow, lightly compacted snow and compacted snow (0-1.67 m); (2) fall layers consisting of faceted crystals with no signs of melt $(1.67-2.79 \mathrm{~m})$, where the boundary between fall and winter layers was not clearly located; (3) late-summer layers, consisting of loose and coarse faceted crystals and hoar, with thin $(1-5 \mathrm{~mm})$ ice layers (2.79-3.17 m); and (4) the mid-summer layer of 2000, consisting of iced firn, ice lenses and ice pipes $(3.17 \mathrm{~m}$ to bottom of the pit). At $85 \mathrm{~mm}$ depth, there was a visible dirt layer, which was $15 \mathrm{~mm}$ thick.

KT had the following seasonal sequence: (1) the uppermost $0.48 \mathrm{~m}$, consisting of faceted-crystal snow, compacted snow, thin ice layers $(1-5 \mathrm{~mm})$ and a $60 \mathrm{~mm}$ thick visible dirt layer at $0.21 \mathrm{~m}$ depth (Fig. 3a); (2) compacted snow with no signs of melt $(0.48-1.11 \mathrm{~m})$; (3) faceted-crystal snow with no signs of melt $(1.11-2.51 \mathrm{~m})$; (4) iced firn containing 2-15 mm ice layers $(2.51-2.91 \mathrm{~m})$; (5) facetedcrystal snow containing $10-50 \mathrm{~mm}$ ice layers and ice pipes
(2.91-3.51 m); (6) fine-grained firn (3.51-5.39m); and (7) iced firn including a $10 \mathrm{~mm}$ ice layer $(5.39 \mathrm{~m}$ to bottom of the core). Layers in (1) are those affected by the surface melting of late spring or early summer 2001. We located the seasons as follows: $(1,2)$ winter/spring 2000/01; (3) fall 2000, where the boundary between fall 2000 and winter 2000/01 was not clearly defined; (4) summer 2000; (5) spring 2000, where snow in this layer had probably been affected by the meltwater drained from the summer layer of 2000; (6) winter/spring 1999/2000 and fall 1999; and (7) summer 1999.

At sites KTU and $\mathrm{KC}$, intermittent summer melting forms thin melt layers, which usually allow for identification of the previous summer layer (Goto-Azuma and others, 2003). At KTU we located the 2000 summer surface just above a $5 \mathrm{~mm}$ ice layer at $4.91 \mathrm{~m}$ depth. On the other hand, very little or no summer melting in 2000 at both KC (where limited melting occurs in some summers) and PRC (in the dry snow zone where only very slight melting occurs in some summers due to shortwave radiation) meant that there were no visible signs of the 2000 summer surface at either site.

When members of the drill team reached the Mount Logan area on 8 May 2001, they found widespread reddish-brown dirt on or just below the snow surface (Zdanowicz and others, 2006). This turned out to be visible evidence of a major fallout of Asian dust that occurred in April 2001 (Jaffe and others, 2003; Uno and others, 2004; Zdanowicz and others, 2006). At the lower sites $(<3000 \mathrm{~m})$ QSD and QS, the dust was dispersed on the snow surface as a thin $(0.01-0.03 \mathrm{~m})$ and patchy reddish-brown layer (Zdanowicz and others,

Table 1. List of sampling sites

\begin{tabular}{lcccc}
\hline $\begin{array}{l}\text { Sampling } \\
\text { site }\end{array}$ & Altitude & $\begin{array}{c}\text { Depth } \\
\text { of pit }\end{array}$ & $\begin{array}{c}\text { Depth } \\
\text { of core }\end{array}$ & $\begin{array}{c}\text { Date } \\
\text { sampled }\end{array}$ \\
& ma.s.I. & $\mathrm{m}$ & $\mathrm{m}$ & \\
\hline QSD & 2420 & 3.60 & & $22-23$ May \\
QS & 2780 & 4.21 & & $15-18$ May \\
KT & 3180 & 3.40 & $3.40-5.68$ & $12-14$ June \\
KTU & 3860 & 1.70 & $1.70-5.88$ & $18-20$ June \\
KC & 4135 & 4.30 & $4.30-9.475$ & $21-24$ June \\
PRC & 5340 & 1.00 & & 25 May \\
\hline
\end{tabular}




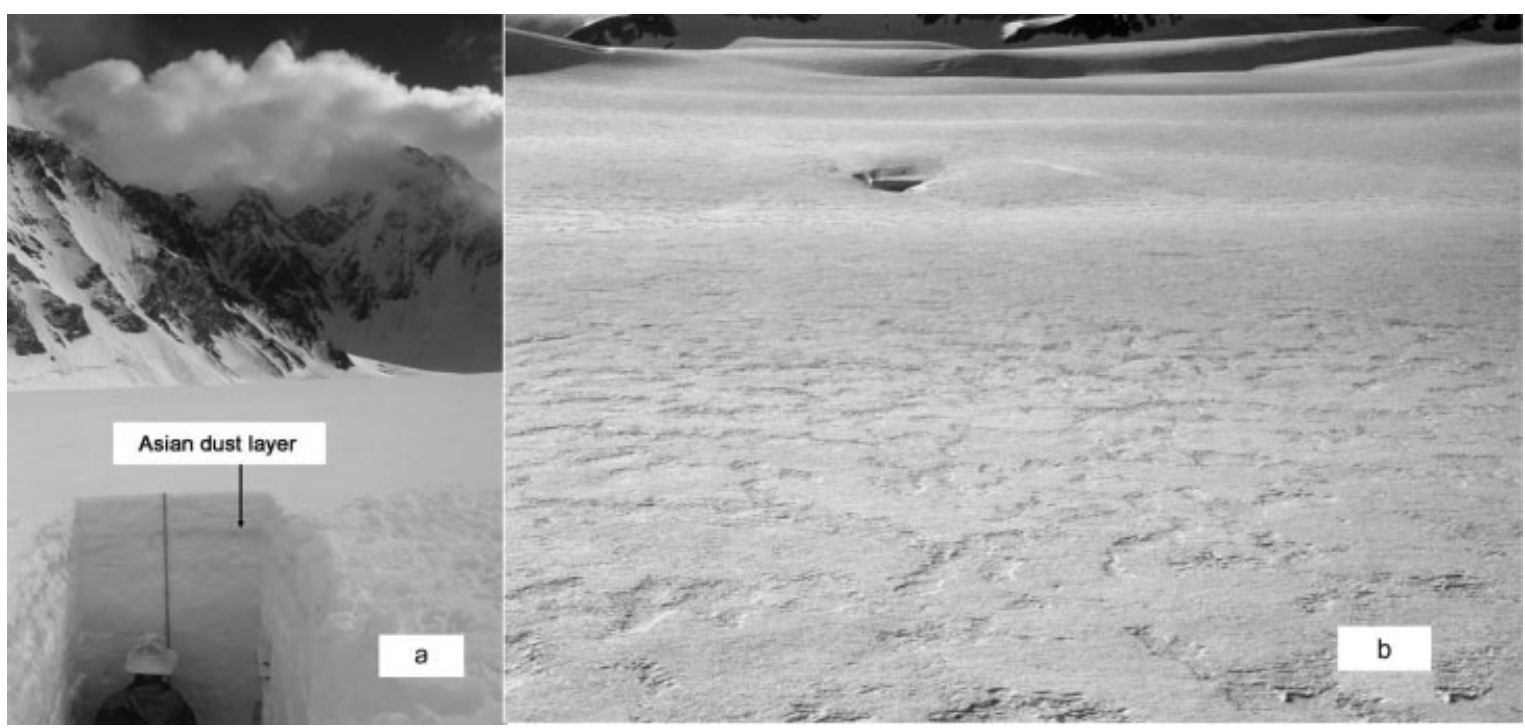

Fig. 3. (a) The Asian dust layer in the pit at KT. (b) An aerial photograph taken above Quintino Sella Glacier on 27 June 2001 , illustrating the patchy snow surface formed by the heterogeneous melt rate due to the dirt cover. Though the scale of the photograph is not known, the scale of the patchiness is on the order of $2-3 \mathrm{~m}$.

2006). Later in the season when pit sampling was done at QS, the dust was found buried under the snow. On the other hand, at QSD, when the sampling was done in late May, the dust was partially buried under the snow but still visible on the surface, due to heterogeneous wind scour. Higher up at King Trench (KT and KTU) and KC, the dust was found as a thicker layer $(0.05-0.13 \mathrm{~m})$ below the snow surface. Figure 3a displays the dust layer observed in the pit at KT.

At sites QSD, QS, KT, KTU and KC, the dust was heterogeneous, being visible in some places and not visible only a few meters away. The dust was visible in the pits at QS, KT and KTU, whereas it was not visible in the pits at QSD, KC and PRC. But even where the dust was not visible, the dust layer was always recognizable because it was denser and more compact than snow immediately above or below it (Zdanowicz and others, 2006) due to somewhat warmer temperatures and/or moist conditions during dust deposition, a post-deposition albedo (shortwave) effect or both. This distinctive dust layer served as an excellent time marker (Goto-Azuma and others, 2003). During the melt season, below about $3000 \mathrm{~m}$, melting exposed the layer at the surface and lowered the albedo, thereby increasing the melt rate to produce a patchy surface in terms of dirt cover (Fig. 3b).

\section{Chemical stratigraphy}

Figure 4 compares profiles of $\delta^{18} \mathrm{O}, \mathrm{Ca}^{2+}$ and $\mathrm{NO}_{3}{ }^{-}$from the six sites on Mount Logan. Note that since sites QSD and QS

Table 2. Correlation coefficients for $\delta^{18} \mathrm{O}$ between the lower five sites

\begin{tabular}{lrllll}
\hline Sampling site & QSD & QS & KT & KTU & KC \\
\hline QSD & 1 & & & & \\
QS & 0.82 & 1 & & & \\
KT & -0.18 & 0.07 & 1 & & \\
KTU & -0.02 & 0.25 & 0.85 & 1 & \\
KC & 0.19 & 0.40 & 0.59 & 0.74 & 1 \\
\hline
\end{tabular}

are located in the wet-snow zone, $\delta^{18} \mathrm{O}$ and ion concentrations below the previous summer surface would have been disturbed with respect to those at the time of snow deposition.

The Asian dust layer was associated with high ion concentrations. Though it was not visible in the pits at QSD, KC and PRC, it could be recognized from its ion signature. With the exception of $\mathrm{NO}_{3}{ }^{-}$and $\mathrm{SO}_{4}{ }^{2-}$ at $\mathrm{KC}$, concentrations of $\mathrm{Ca}^{2+}, \mathrm{NO}_{3}{ }^{-}, \mathrm{SO}_{4}{ }^{2-}, \mathrm{NH}_{4}{ }^{+}, \mathrm{K}^{+}$and $\mathrm{Mg}^{2+}$ $\left(\mathrm{K}^{+}\right.$and $\mathrm{Mg}^{2+}$ not presented here) were all high in the Asian dust layer, particularly where it was visible. Concentrations of $\mathrm{Na}^{+}$and $\mathrm{Cl}^{-}$were also high in the Asian dust layer at most of the sites.

What we consider corresponding peaks are marked with thin dashed lines in Figure 4. We estimated the depth of the summer 2000 surface at both KC and PRC, where lack of melting did not allow the development of a distinct summer layer, by comparison among the profiles of $\delta^{18} \mathrm{O}$ and various ion concentration profiles. At KC, the 2000 summer surface was located at $5.185 \mathrm{~m}$. This is consistent with a first-order estimate of snow deposition between summer 2000 and spring 2001, deduced from the fact that the automatic weather station, which had been installed at $\mathrm{KC}$ in late July 2000, was found buried in snow when KC was revisited in May 2001. At PRC, the 2000 summer surface was located at $0.75 \mathrm{~m}$, yielding $0.37 \mathrm{~m}$ w.e. snow deposition between summer 2000 and spring 2001, which seems to be reasonable because this is about $60 \%$ of the annual mean accumulation rate at the site (Fisher and others, 2004). By normalizing the depth between the Asian dust layer (spring 2001) and the summer 2000 surface at each site, we calculated correlation coefficients of $\delta^{18} \mathrm{O}$ and ion profiles between sites QSD, QS, KT, KTU and KC. PRC was excluded from the correlation analysis because the site had significantly fewer samples than other sites.

Based on the $\delta^{18} \mathrm{O}$ correlation analysis (Table 2), we can divide the lower five sites into two groups: QSD and QS at the lower altitudes, and KT, KTU and KC at the midaltitudes. Though we did not include PRC in the correlation analysis, PRC is likely on its own at the highest altitude, 

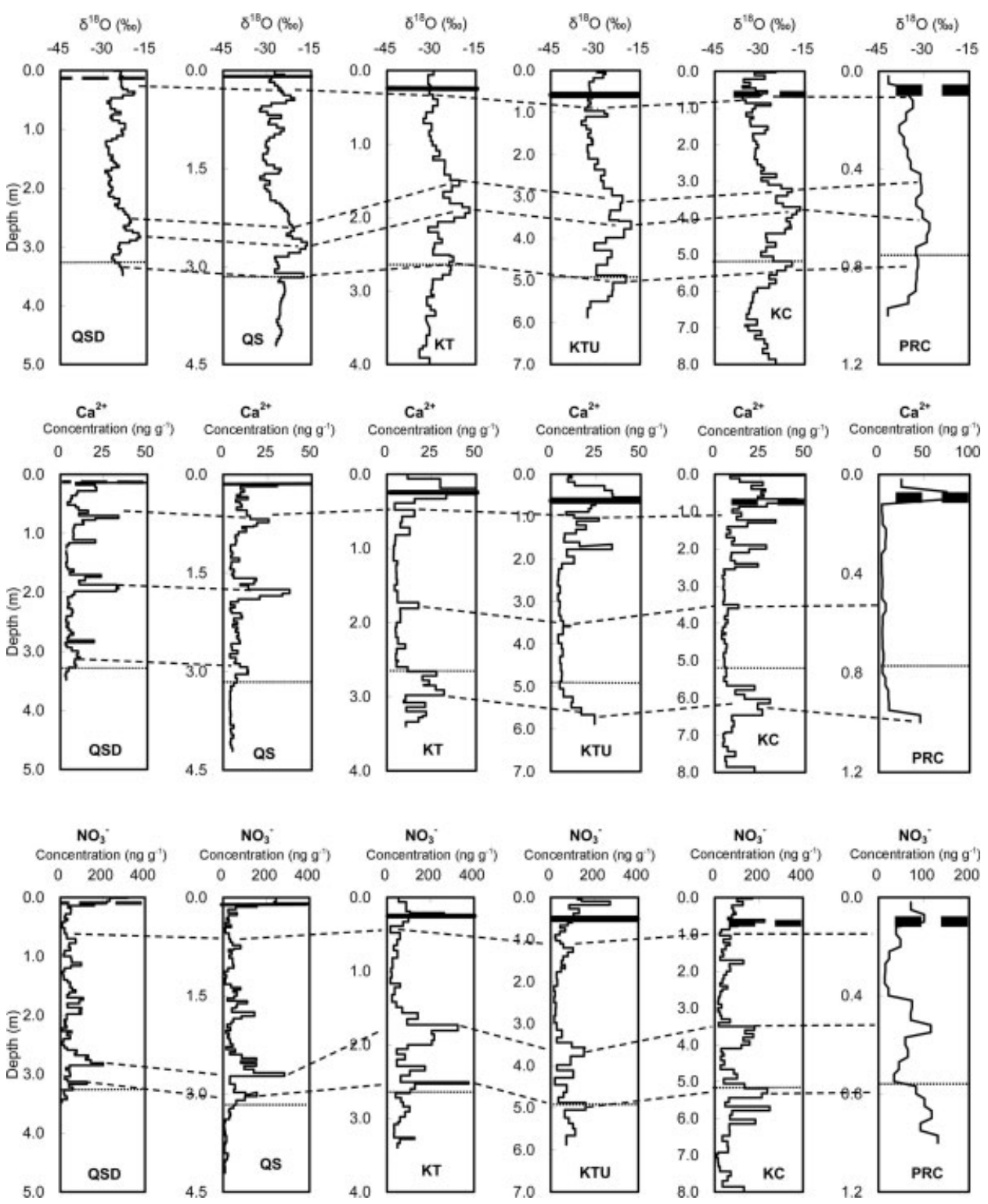

Fig. 4. Profiles of $\delta^{18} \mathrm{O}, \mathrm{Ca}^{2+}$ and $\mathrm{NO}_{3}{ }^{-}$. Corresponding peaks at different sites are connected with thin dashed lines. The Asian dust layer is shown by either a thick solid line (where it was visible) or a thick dashed line (where it was not visible). The thickness of each thick line corresponds to that of the dust layer. The location of the end of the 2000 summer melt season at each site is denoted by a dotted line.

taking into account the much lower accumulation rate here than at the lower five sites, which is discussed in a later section. Correlation coefficients for ions show a spatial tendency similar to those for $\delta^{18} \mathrm{O}$, while they were generally lower than those for $\delta^{18} \mathrm{O}$. Division into three groups is likely due to the difference in moisture source and its transport pathway: sites in the planetary boundary layer $(<3000 \mathrm{~m}$ a.s.l.) being affected mainly by local sources; sites in the upper geostrophic flow region (>5000 ma.s.l.) being affected by distant sources; and sites in the mixed layer (3000-5000 m a.s.l.) being affected by both sources (Holdsworth and others, 1991; Holdsworth, 2001; Holdsworth and Krouse, 2002). The occasional difference in the timing of precipitation at different altitudes would also contribute to the differences between the higher and lower sites. In fact, weather reports from QS, KC and PRC were frequently different during the 2001 and 2002 field seasons, when the three stations were manned most of the time. However, it should be noted that though a series of depth profiles of $\delta^{18} \mathrm{O}$ and ions shows spatial variations, characteristic peaks can usually be traced across all the profiles. This fact suggests that there is a commonality between snowfall events and deposition of aerosols at the lower and higher sites; they do not take place in a completely independent manner. Frontal systems and, in particular, occluded fronts of stalled cyclones, which are common in this region, bring moisture from both local and distant sources to Mount Logan during the same storm events, where predominance of local vs distant sources depends on the altitude (Holdsworth and others, 1991). The variation in local snowfall at different altitudes would produce noise superimposed on the dominant signal from the larger storm events which affect all altitudes.

\section{Seasonal variations of $\delta^{18} \mathrm{O}$ and ions}

We now discuss the variations with depth of $\delta^{18} \mathrm{O}, \mathrm{Ca}^{2+}$, $\mathrm{Na}^{+}, \mathrm{Cl}^{-}, \mathrm{NO}_{3}{ }^{-}, \mathrm{SO}_{4}{ }^{2-}, \mathrm{MSA}$ and $\mathrm{NH}_{4}{ }^{+}$to see if there are any variations associated with seasonality (Fig. 5). At QSD, QS, $\mathrm{KT}$ and KTU, where visible stratigraphy allowed easy identification of the 2000 summer surface, the $\delta^{18} \mathrm{O}$ 
maximum was seen right above it, indicating that $\delta^{18} \mathrm{O}$ peaks in late summer/fall. On the other hand, the $\delta^{18} \mathrm{O}$ minimum was observed in winter layers. At KC, where we could not identify the summer 2000 layer from visible stratigraphy, high correlation of $\delta^{18} \mathrm{O}$ between $\mathrm{KC}$ and KTU suggests that $\delta^{18} \mathrm{O}$ at KC shows seasonality similar to that at lower sites. Additionally, a pit dug at KC in 2002, where the previous summer (the summer 2001) layer was easily identified by visible stratigraphy in this particular year (Goto-Azuma and others, 2003), exhibited the same seasonal variation of $\delta^{18} \mathrm{O}$ (Goto-Azuma and others, unpublished information). This fact supports the same seasonality of $\delta^{18} \mathrm{O}$ at KC. It would be reasonable to assume the same seasonality also at PRC, if we consider the resemblance of $\delta^{18} \mathrm{O}$ profiles at KC and PRC, with the assumed depth of the 2000 summer surface. The seasonality of $\delta^{18} \mathrm{O}$ observed in this study (late-summer/fall maxima and winter minima) is similar to that reported for sites on the Mount Logan plateau (where the elevation is everywhere $>5000 \mathrm{~m}$ ) (Holdsworth and others, 1991). However, Wake and others (2002) and Yalcin and others (2003, 2006b) reported summer maxima of $\delta^{18} \mathrm{O}$ at nearby Eclipse Icefield (altitude $3017 \mathrm{~m}$ ). The reason for this difference in seasonality between Mount Logan sites and Eclipse is as yet unknown.

The ion records also display seasonal variations, with more noise than $\delta^{18} \mathrm{O}$. At most of the sites, MSA peaks slightly before $\delta^{18} \mathrm{O}$ does, i.e. in late summer/early fall. Other ions show higher concentrations in the Asian dust layer at most of the sites. The dust layer was formed by an episodic event and it somehow overwhelms the seasonal cycle of the various chemical species we are studying. However, most of the ions show peaks in the late winter/ spring broader than the thickness of the dust layer, with the exception of PRC. As Asian dust events, though they are non-periodic, are primarily springtime phenomena (e.g. Merrill and others, 1989; Jaffe and others, 1999), winter/ spring peaks of dust-derived ions, such as $\mathrm{Ca}^{2+}$, might then be considered as a potential annual marker in Mount Logan snow. Furthermore, sea-salt ions $\mathrm{Na}^{+}$and $\mathrm{Cl}^{-}$, along with $\mathrm{Ca}^{2+}$ (Fig. 5), at all the sites above $3000 \mathrm{~m}$ (i.e. KT, KTU, KC and PRC), show peaks only in winter/spring. At the sites below $3000 \mathrm{~m}$ (i.e. QSD and QS), seasonal input timing of these ions is similar to that at the higher sites, with additional minor peaks. The seasonal variations of $\mathrm{Ca}^{2+}, \mathrm{Na}^{+}$and $\mathrm{Cl}^{-}$ observed in this study are similar to those at Eclipse Icefield, reported by Yalcin and Wake (2001) and Yalcin and others (2003, 2006b).

Ammonium generally shows a spring maximum, with a few spikes added to this overall trend. Episodic events such as forest fires (Yalcin and others, 2006a) could produce such spikes and occasionally disturb the general seasonality. Yalcin and others (2006b) also reported the similar seasonality of $\mathrm{NH}_{4}{ }^{+}$at Eclipse Icefield. Concentrations of $\mathrm{NO}_{3}{ }^{-}$ and $\mathrm{SO}_{4}{ }^{2-}$, peaking in winter/spring together with other ions, also show peaks in the late summer/fall. Contradictory to our finding, Yalcin and others (2006b) reported latespring/summer peaks only. Though our study covers only a single year, seasonality found here might have important implications, since anthropogenic inputs of $\mathrm{NO}_{3}{ }^{-}$and $\mathrm{SO}_{4}{ }^{2-}$ have added a late-winter/early-spring peak to the natural summer peak in the North Atlantic sector of the Arctic (e.g. Finkel and others, 1986; Goto-Azuma and others, 1997). Further investigation is needed to draw a firm conclusion.

\section{Altitudinal variations of $\delta^{18} \mathrm{O}$ and ions}

We calculated the snow and ion fluxes, and averages of $\delta^{18} \mathrm{O}$ and ion concentrations for the period between the end of the summer 2000 melt season and the April 2001 Asian dust event, where there are good time markers. Snow and ions deposited in the Asian dust layer have not been included in the calculation. The results are plotted vs altitude in Figures 6 and 7. Methanesulfonate (MSA), $\mathrm{Mg}^{2+}$ and $\mathrm{K}^{+}$data at QS and $\mathrm{KC}$ have not been included due to the very low concentrations which could not be measured with sufficient accuracy in some depth intervals of the pits.

Snow deposition is clearly not a simple function of altitude (Fig. 6). Between the end of summer 2000 and April 2001, snow deposition was highest at KC and lowest at PRC. King Col and King Trench usually receive higher snow accumulation, possibly because these sites are more sheltered and less affected by scouring, but also because local orographic effects tend to enhance snowfall there (Keeler, 1969), in contrast to the plateau, which receives much less precipitation (Keeler, 1969; Holdsworth and others, 1984, 1988; Holdsworth and Peake, 1985). KC is also subject to the local effects of larger storms because it is situated in the lee of the summit of Schoening Ridge, which would be another factor contributing to a high accumulation rate.

As was reported in earlier papers (Holdsworth and others, 1991; Holdsworth, 2001; Holdsworth and Krouse, 2002), altitudinal variation of the mean $\delta^{18} \mathrm{O}$ between summer 2000 and April 2001 (Fig. 7) follows a characteristic staircase structure with a significant step between 3200 and $4000-5000 \mathrm{~m}$. There is no clear and consistent relationship between altitude and most of the ions in terms of either concentration or flux. In general terms, the highest site (PRC) lies separate from all the lower sites. This is discussed by Fisher and others (2004) who conclude that the Logan plateau is in the path of air-mass trajectories of much greater length than the areas below it. Below the plateau, fluxes of some of the ions, such as $\mathrm{Ca}^{2+}, \mathrm{NO}_{3}{ }^{-}, \mathrm{SO}_{4}{ }^{2-}$ and $\mathrm{NH}_{4}{ }^{+}$, show weak positive relationships with elevation (Fig. 6). In contrast, fluxes and average concentrations of $\mathrm{Na}^{+}$and $\mathrm{Cl}^{-}$ (Figs 6 and 7) all decrease with altitude, though high snow deposition at KTU and KC due to the local orographic effects somewhat obscures the general decreasing trend in fluxes of $\mathrm{Na}^{+}$and $\mathrm{Cl}^{-}$(Fig. 6). As the $\mathrm{Cl}^{-} / \mathrm{Na}^{+}$ratio in most of the pit samples is close to that of sea water (1.8), suggesting that sea salt is the major source for $\mathrm{Cl}^{-}$and $\mathrm{Na}^{+}$, we would expect the atmospheric concentrations of these ions and hence the fluxes and concentrations to decrease with altitude, i.e. distance from the source effect.

Fluxes of $\mathrm{Ca}^{2+}, \mathrm{NO}_{3}{ }^{-}, \mathrm{SO}_{4}{ }^{2-}$ and $\mathrm{NH}_{4}{ }^{+}$increase with snow deposition, whereas those of $\mathrm{Na}^{+}$and $\mathrm{Cl}^{-}$have no relationship with snow deposition (Fig. 8). This suggests that the main scavenging process for $\mathrm{Ca}^{2+}, \mathrm{NO}_{3}{ }^{-}, \mathrm{SO}_{4}{ }^{2-}$ and $\mathrm{NH}_{4}{ }^{+}$in this area is 'rain-out', i.e. wet, rather than dry, deposition. A similar result has been reported by Yalcin and others (2006b). Although we did not include the Asian dust layer in the flux calculation, wet deposition would be an important scavenging process also for the Asian dust at the sites with high snow accumulation rate, because we noticed a thicker Asian dust layer at sites with higher snow deposition.

The distinctly Asian dust layer found in Mount Logan snow indicates that Asian dust is an important source of the 

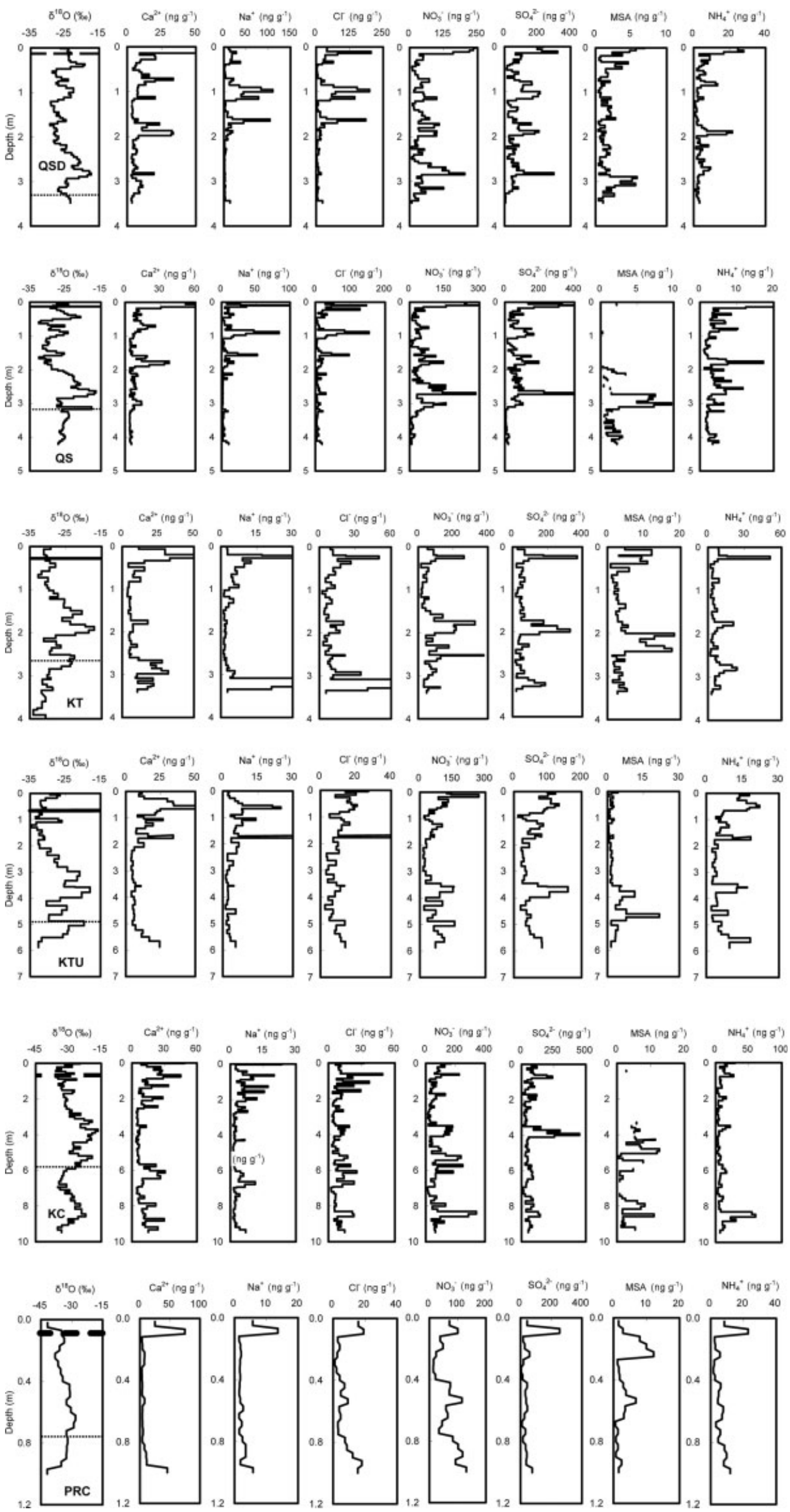

Fig. 5. Profiles of $\delta^{18} \mathrm{O}, \mathrm{Ca}^{2+}, \mathrm{Na}^{+}, \mathrm{Cl}^{-}, \mathrm{NO}_{3}{ }^{-}, \mathrm{SO}_{4}{ }^{2-}, \mathrm{MSA}$ and $\mathrm{NH}_{4}{ }^{+}$. Location of the Asian dust layer is shown by either a thick solid line (where it was visible) or a thick dashed line (where it was not visible) in each $\delta^{18} \mathrm{O}$ diagram. The thickness of each thick line corresponds to that of the dust layer. The location of the end of the summer 2000 melt season is denoted by a dotted line in each $\delta^{18} \mathrm{O}$ diagram. 

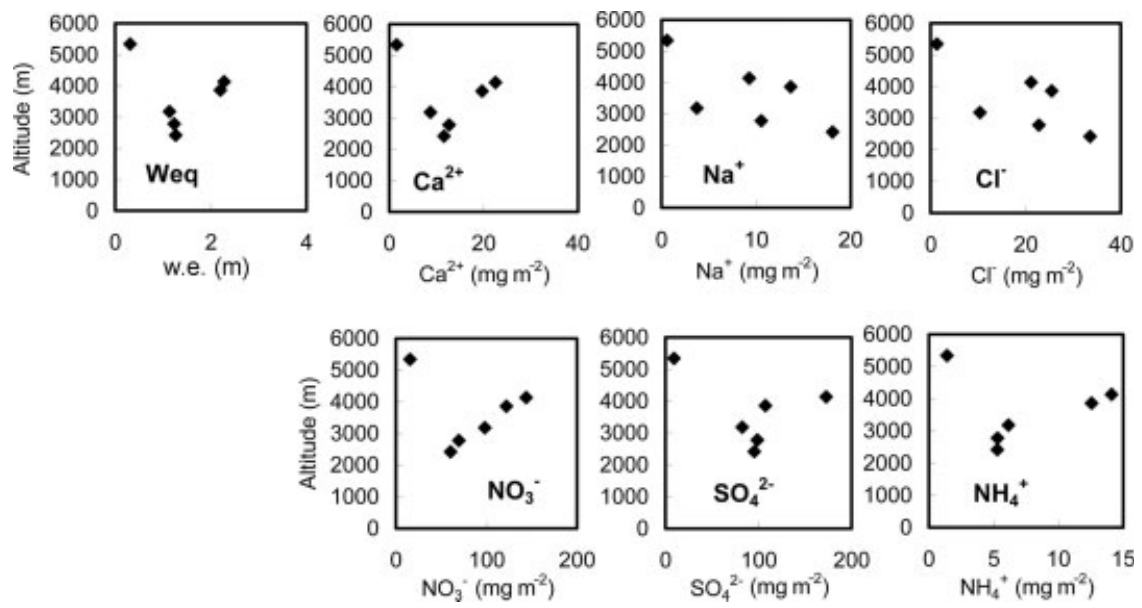

Fig. 6. Deposition fluxes of snow and ions between end of the summer 2000 melt season and April 2001, vs altitude.

dust deposited on Mount Logan (Zdanowicz and others, 2006). Since $\mathrm{Ca}^{2+}$ is mainly of continental dust origin, Asian dust may also be an important source of $\mathrm{Ca}^{2+}$ in Mount Logan snow.

Major sources for $\mathrm{NO}_{3}{ }^{-}$and $\mathrm{SO}_{4}{ }^{2-}$ may vary with altitude. At a lower-altitude site, Eclipse Icefield, anthropogenic pollutants are reported to be major sources (Yalcin and Wake, 2001). On the contrary, no anthropogenic impacts have been observed at a higher site (5340 ma.s.I.) on North West Col (Holdsworth and Peake, 1985), where snow contains aerosols scavenged from the middle and/or upper troposphere (Monaghan and Holdsworth, 1990). Since the sampling sites in this study cover both altitudes, effects of anthropogenic sources are expected to vary with altitude. Forest fires would be important sources for $\mathrm{NO}_{3}{ }^{-}$ and $\mathrm{NH}_{4}{ }^{+}$(Holdsworth and others, 1988, 1996; Yalcin and others, 2006a).

Seasonal variations of heavy metals in Alpine ice have been reported to be largely linked with the changing vertical structure of the regional troposphere, which prevents the transfer of pollutants to higher altitudes in winter but not in summer (Van de Velde and others, 1998). If this is the case for ions in Mount Logan snow, though little is known, seasonal variations of ions could differ with altitude.

\section{CONCLUSIONS}

Samples from six snow pits and three shallow cores were collected in May and June 2001 to investigate seasonal and spatial variations of ion chemistry and stable isotopes. At the lower three sites (QSD, QS and KT), regular summer melting enabled us to identify the previous summer layer and examine the seasonal nature of the visible stratigraphy in the pits. At a higher site, KTU, the summer layer was defined by a thin ice layer. Therefore, seasonal variations of $\delta^{18} \mathrm{O}$ and ions at QSD, QS, KT and KTU were investigated by comparing these profiles with the visible stratigraphy. For the uppermost two sites, where the summer 2000 surface was barely recognizable, the seasonal variations of $\delta^{18} \mathrm{O}$ and ions were deduced by comparing the $\delta^{18} \mathrm{O}$ profiles with those at the lower sites. Though the seasonal variations showed slight differences between sites, the following seasonality was generally seen: (1) $\delta^{18} \mathrm{O}, \mathrm{NO}_{3}{ }^{-}$ and $\mathrm{SO}_{4}{ }^{2-}$ peak in late summer/fall; (2) $\mathrm{NO}_{3}{ }^{-}$and $\mathrm{SO}_{4}{ }^{2-}$ occasionally show a secondary peak in winter/spring; (3) the marine biogenic species MSA peaks in late summer/early fall; (4) both sea-salt species $\left(\mathrm{Na}^{+}\right.$and $\left.\mathrm{Cl}^{-}\right)$ and dust-derived species $\mathrm{Ca}^{2+}$ peak in winter/spring; and (5) $\mathrm{NH}_{4}^{+}$generally shows a spring maximum, with a few spikes added to this overall trend. The seasonal variations
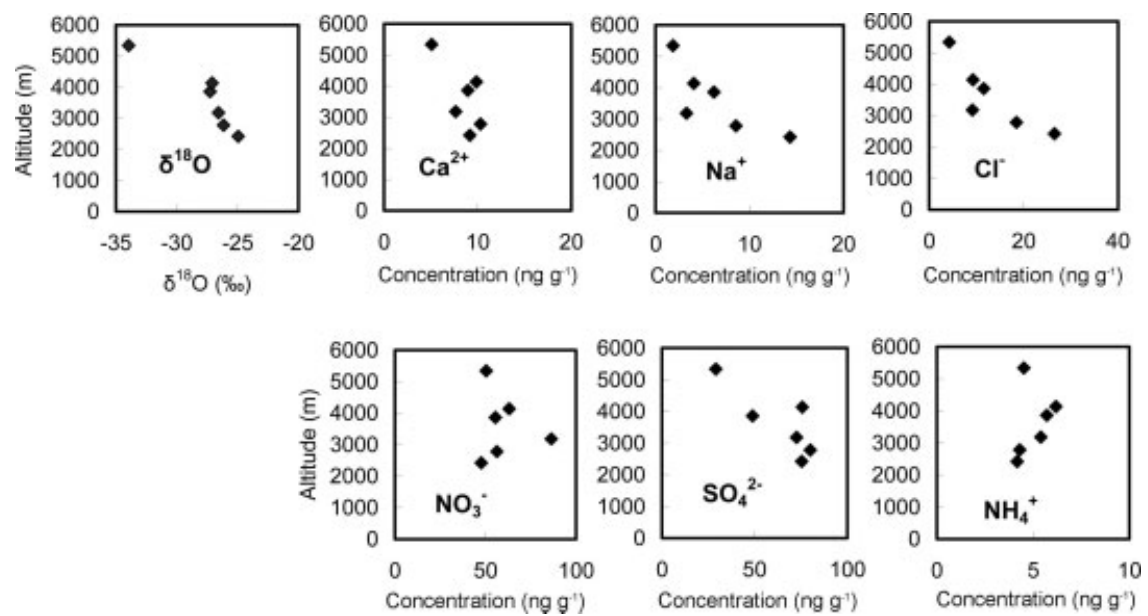

Fig. 7. Mean $\delta^{18} \mathrm{O}$ and ion concentrations between end of the summer 2000 melt season and April 2001, vs altitude. 

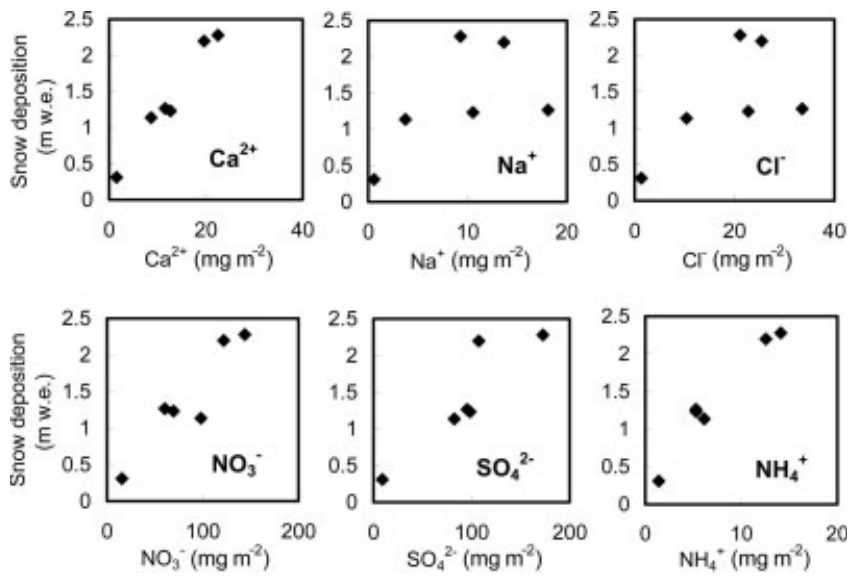

Fig. 8. Deposition fluxes of ions between end of the summer 2000 melt season and April 2001, vs snow deposition.

of $\delta^{18} \mathrm{O}$ and ions should allow a high time-resolution dating of the King Col core (where there is a paucity of stratigraphic markers). Characteristic peaks in $\delta^{18} \mathrm{O}$ and ion profiles were observed in common at all the sites. However, greater similarity of $\delta^{18} \mathrm{O}$ and ion profiles was found between the lower two sites (QSD and QS) and among the higher three sites (KT, KTU and $\mathrm{KC}$ ), with the highest site (PRC) possibly having its own distinct signature. This is probably because of different sources and transport pathways of moisture and chemical constituents for higher and lower sites.

Altitudinal variation of $\delta^{18} \mathrm{O}$ was similar to that reported by previous studies (Holdsworth and others, 1991; Holdsworth, 2001; Holdsworth and Krouse, 2002). Altitudinal variations in the fluxes of $\mathrm{Ca}^{2+}, \mathrm{NO}_{3}{ }^{-}, \mathrm{SO}_{4}{ }^{2-}$ and $\mathrm{NH}_{4}{ }^{+}$ followed the same pattern as snow accumulation rates, suggesting that between the end of summer 2000 and April 2001, rain-out/wet deposition was the dominant scavenging/ deposition process for these ions. There was no clear and consistent relationship between altitude and most of the ions, except for $\mathrm{Na}^{+}$and $\mathrm{Cl}^{-}$, in terms of either concentration or flux. However, it should be noted that the results presented in this paper are characteristic of a single year and that year-to-year variations might exist.

\section{ACKNOWLEDGEMENTS}

This study was supported by Grant-in-Aid for Scientific Research on Priority Areas (B) (Project No. 11208202) from the Ministry of Education, Culture, Sports, Science and Technology of Japan, and by the International Arctic Research Center, University of Alaska Fairbanks. We thank all the 2001 Mount Logan expedition members and D.A. Fisher (Geological Survey of Canada) for logistical support. We also thank Parks Canada and the Arctic Institute of North America for helpful cooperation on this project, and K. Yalcin and E. Osterberg for helpful reviews of the manuscript.

\section{REFERENCES}

Finkel, R.C., C.C. Langway, Jr and H.B. Clausen. 1986. Changes in precipitation chemistry at Dye 3, Greenland. J. Geophys. Res., 91(D9), 9849-9855.
Fisher, D.A. and 20 others. 2004. Stable isotope records from Mount Logan and Eclipse ice cores and nearby Jellybean Lake. Water cycle of the North Pacific over 2000 years and over 5 vertical kilometers: sudden shifts and tropical connections. Geogr. Phys. Quatern., 58(2-3), 337-352.

Goto-Azuma, K., R.M. Koerner, M. Nakawo and A. Kudo. 1997. Snow chemistry of Agassiz Ice Cap, Ellesmere Island, Northwest Territories, Canada. J. Glaciol., 43(144), 199-206.

Goto-Azuma, K. and 6 others. 2003. An overview of the Japanese glaciological studies on Mt. Logan, Yukon Territory, Canada in 2002. Bull. Glaciol. Res., 20, 65-72.

Holdsworth, G. 2001. Calibration changes in the isotopic thermometer for snow according to different climatic states. Geophys. Res. Lett., 28(13), 2625-2628.

Holdsworth, G. and H.R. Krouse. 2002. Altitudinal variation of the stable isotopes of snow in regions of high relief. J. Glaciol., 48(160), 31-41.

Holdsworth, G. and E. Peake. 1985. Acid content of snow from a mid-troposphere sampling site on Mount Logan, Yukon Territory, Canada. Ann. Glaciol., 7, 153-160.

Holdsworth, G., M. Pourchet, F.A. Prantl and D.P. Meyerhof. 1984. Radioactivity levels in a firn core from the Yukon Territory, Canada. Atmos. Environ., 18(2), 461-466.

Holdsworth, G., H.R. Krouse and E. Peake. 1988. Trace-acid ion content of shallow snow and ice cores from mountain sites in western Canada. Ann. Glaciol., 10, 57-62.

Holdsworth, G., S. Fogarasi and H.R. Krouse. 1991. Variation of the stable isotopes of water with altitude in the St. Elias Mountains of Canada. J. Geophys. Res., 96(D4), 7483-7494.

Holdsworth, G. and 8 others. 1996. Historical biomass burning: late 19th century pioneer agriculture revolution in northern hemisphere ice core data and its atmospheric interpretation. J. Geophys. Res., 101(D18), 23,317-23,334.

Jaffe, D. and 12 others. 1999. Transport of Asian air pollution to North America. Geophys. Res. Lett., 26(6), 711-714.

Jaffe, D., J. Snow and O. Cooper. 2003. The 2001 Asian dust events: transport and impact on surface aerosol concentrations in the US. EOS, Trans. AGU, 84(46), 501-507.

Keeler, C.M. 1969. Snow accumulation on Mount Logan, Yukon Territory, Canada. Water Resour. Res., 5(3), 719-723.

Legrand, M. and P. Mayewski. 1997. Glaciochemistry of polar ice cores: a review. Rev. Geophys., 35(3), 219-243.

Mantua, N.J., S.R. Hare, Y. Zhang, J.M. Wallace and R.C. Francis. 1997. A Pacific interdecadal climate oscillation with impacts on salmon production. Bull. Am. Meteorol. Soc., 78, 1069-1079.

Merrill, J.T., M. Uematsu and R. Bleck. 1989. Meteorological analysis of long range transport of mineral aerosols over the north Pacific. J. Geophys. Res., 94(D6), 8584-8598.

Monaghan, M.C. and G. Holdsworth. 1990. The origin of non-seasalt sulphate in the Mount Logan ice core. Nature, 343(6255), 245-248.

Moore, G.W.K., G. Holdsworth and K. Alverson. 2001. Extratropical response to ENSO as expressed in an ice core from the Saint Elias mountain range. Geophys. Res. Lett., 28(18), 3457-3460.

Moore, G.W.K., G. Holdsworth and K. Alverson. 2002. Climate change in the North Pacific region over the past three centuries. Nature, 420(6914), 401-403.

Shiraiwa, T. and 7 others. 2003. Ice core drilling at King Col, Mount Logan 2002. Bull. Glaciol. Res., 20, 57-63.

Trenberth, K.E. 1990. Recent observed interdecadal climatic change in the Northern Hemisphere. Bull. Am. Meteorol. Soc., 71, 988-993.

Trenberth, K.E. and J.W. Hurrell. 1994. Decadal atmosphere-ocean variations in the Pacific. Climate Dyn., 9, 303.

Uno, I. and 14 others. 2004. Numerical study of Asian dust transport during the springtime of 2001 simulated with the Chemical Weather Forecasting System (CFORS) model. J. Geophys. Res., 109, D19S24. (10.1029/2003JD004222.) 
Van de Velde, K. and 6 others. 1998. Seasonal variations of heavy metals in the 1960s Alpine ice: sources versus meteorological factors. Earth Planet Sci. Lett., 164(3), 521-533.

Wake, C.P., K. Yalcin and N.S. Gundestrup. 2002. The climate signal recorded in the oxygen-isotope, accumulation and majorion time series from the Eclipse ice core, Yukon Territory, Canada. Ann. Glaciol., 35, 416-422.

Yalcin, K. and C.P. Wake. 2001. Anthropogenic signals recorded in an ice core from Eclipse Icefield, Yukon Territory, Canada. Geophys. Res. Lett., 28(23), 4487-4490.

Yalcin, K., C.P. Wake and M. Germani. 2003. A 100-year record of North Pacific volcanism in an ice core from Eclipse Icefield,
Yukon Territory, Canada. J. Geophys. Res., 108(D1), 4012. (10.1029/2002JD002449.)

Yalcin, K., C.P. Wake, K.J. Kreutz and S.I. Whitlow. 2006a. A 1000$\mathrm{yr}$ record of forest fire activity from Eclipse Icefield, Yukon, Canada. The Holocene, 16(2), 200-209.

Yalcin, K., C.P. Wake, S. Kang, K.J. Kreutz and S.I. Whitlow. $2006 \mathrm{~b}$. Seasonal and spatial variability in snow chemistry at Eclipse Icefield, Yukon, Canada. Ann. Glaciol., 43 (see paper in this volume).

Zdanowicz, C. and 7 others. 2006. Asian dustfall in the St. Elias Mountains, Yukon, Canada. Geochim. Cosmochim. Acta, 70(14), 3493-3507. 